\title{
TRANSFO RMASI SEMATAN KLAUSA RELATIF PADA TEKS TERJEMAHAN ALQURAN YANG MENGANDUNG ETIKA BERBAHASA
}

\author{
Shofiyuddin \\ Universitas PG RI Ronggolawe Tuban \\ Email: shofiunirow@gmail.com \\ D OI: http:/ / dx.doi.org/ 10.17509/ bs_jpbsp.v17i2.9660
}

\begin{abstract}
Abstrak
Penelitian ini bertujuan untuk (1) mengidentifikasi transformasi sematan klausa relatif, (2) menjelaskan proses terjadinya transformasi sematan, dan (3) menjelaskan kaidah transformasi yang terdapat pada teks terjemahan Alquran yang mengandung etika berbahasa. Pengumpulan data dilakukan dengan teknik dokumentasi, simak, dan catat. Data dalam penelitian ini berupa kalimat-kalimat yang terdapat pada terjemahan ayat-ayat Alquran yang mengandung transformasi sematan. Sumber datanya adalah teks terjemahan Alquran yang mengandung etika berbahasa. Analisis data dalam penelitian ini menggunakan metode padan ekstralingual dan padan intralingual. Pengujian keabsahan data menggunakan teknik triangulasi sumber data. Hasil penelitian menunjukkan (1) terdapat 41 kalimat transformasi sematan klausa relatif yang terdapat pada teks terjemahan Alquran yang mengandung etika berbahasa, (2) proses transformasi sematan pada teks terjemahan Alquran yang mengandung etika berbahasa, (3) kaidah transformasi berdasarkan jenis kalimat terbagi menjadi dua, yaitu kalimat kompleks dan kalimat sederhana. Kalimat sederhana hanya terdiri atas satu proses transformasi saja dan dalam penelitian ini terdapat sepuluh.
\end{abstract}

Kata kunci: transformasi sematan klausa relatif; teks terjemahan Alquran; etika berbahasa

\section{TRAN SFORMATION OF RELATIVE EMBEDDED CLAUSES IN THE HOLY QURAN TEXT TRANSLATION CONTAINING LANGUAGE ETHICS}

\begin{abstract}
This research aims to (1) identify kinds of relative embedded clauses transformation; (2) describe the transformation process, and (3) describe the transformation principles of the Holy Q uran translation that contains language ethics. The data collection techniques for the study involved documents mining, observation and recording. The data were in the form of translated sentences of the Quran that contained embedded transformation. The data source was translated text of the Quran that reflected language ethics. Data analysis of this study involved intralingual and extralingual methods. Data triangulation was also employed to cross-check the reliability of the data. The results of the analysis indicate that (1) there are forty-one sentences of relative embedded clauses transformation in the translated text of the Holy Quran that contains language ethics, (2) embedded transformation process in the translation of the Quran contains language ethics, and (3) the transformation principles based on sentence types are of two types: complex and compound sentences. A compound sentence only involved one transformation process, and there are ten such sentences revealed in the present study.
\end{abstract}

Keywords: Relative embedded clauses transformation; translation of the Holy Quran; language ethics. 


\section{PENDAH ULUAN}

Alquran adalah kitab suci umat Islam yang berisi firman Allah yang diturunkan kepada nabi Muhammad dengan perantara malaikat Jibril untuk dibaca, dipahami, dan diamalkan sebagai petunjuk atau pedoman hidup bagi umat manusia (KBBI, 2005). Sebagai sebuah kitab, Alquran menjadi pegangan bagi manusia (khususnya kaum muslimin) untuk melaksanakan aktivitas dalam kehidupannya. Alquran pada dasarnya mengandung tiga pokok ajaran, yaitu ajaran keimanan, ajaran akhlak atau budi pekerti, dan ajaran berbagai rupa hukum yang bersangkutan dengan pergaulan hidup masyarakat bagi insan di dunia. D engan kata lain, Alquran itu mengandung aqidah, syan'ah, dan akhlak.

Salah satu ajaran mengenai akhlak atau budi pekerti yang terdapat dalam Alquran adalah etika dalam berbahasa. Etika berbahasa adalah sistem tindak laku berbahasa menurut norma-norma budaya (Chaer dan Agustina, 2010, p.172). Etika berbahasa mengarahkan manusia dalam menggunakan bahasa dengan benar dan dapat menciptakan saling berterima antara mitra tutur dengan lawan tutur. Markhamah, Ngalim, Muinudinillah, Sabardila, dan Susilowati (2012, p.151) mengutarakan bahwa penggantian yang paling sering muncul pada teks terjemahan Alquran yang mengandung etika berbahasa yaitu penggantian sama tataran, karena pada teks terjemahan Alquran yang mengandung etika berbahasa berisi tentang kalam dari Allah (sebagai penutur) yang disampaikan kepada Nabi Muhammad Saw. (mitra tutur) melalui perantara malaikat Jibril.

Sabardila (2003) dalam penelitiannya yang menggunakan metode digtal Alquran telah menemukan 109 ayat pada teks terjemahan Alquran yang mengandung etika berbahasa. Contoh etika berbahasa yang terdapat dalam teks terjemahan Alquran yang ditemukan oleh Sabardila (2003) adalah melunakkan suara ketika berbicara (surat AlLukman ayat 19), larangan menuduh orang lain tanpa dasar (surat Yasin ayat 76), perintah bersabar ketika mendengar ucapan yang kasar (surat Sadayat 17), dan lain-lain.

Teks terjemahan Alquran (yang mengandung etika berbahasa) dalam bentuk bahasa Indonesia mempunyai variasi pada pembentukan kalimatnya. Salah satu variasi yang ada adalah terdapatnya kalimat turunan atau transformasi. Kalimat transformasi adalah proses pembentukan unsur bahasa dari struktur dasar ke struktur turunan (Samsuri, 1982, p.221).

Terdapat lima proses pembentukan kalimat turunan Bahasa Indonesia, yaitu (1) transformasi tunggal, (2) transformasi sematan, (3) transformasi rapatan, (4) transformasi fokus, (5) transformasi khusus. Transformasi tunggal bertolak dari sebuah kalimat dasar, sedangkan transformasi sematan dan rapatan bertolak dari dua buah kalimat. Transformasi fokus memindahkan unsur-unsur yang difokuskan ke bagian lain dalam kalimat, pada umumnya ke bagian depan. Transformasi khusus merupakan pembentukan kalimat-kalimat turunan secara khusus (Samsuri, 1982, p.221). Pada dasarnya, setiap transformasi merupakan kaidah yang digunakan oleh pengguna bahasa Indonesia untuk membentuk sebuah kalimat.

Penelitian ini difokuskan pada pembahasan kalimat transformasi sematan pada teks terjemahan Alquran yang mengandung etika berbahasa. Teks terjemahan Alquran yang mengandung etika berbahasa yang dijadikan bahan kajian adalah sebagaimana hasil kajian Sabardila (2003) yang menggunakan metode digtal Alquran. Ada lima jenis transformasi sematan, yaitu klausa relatif, pelengkap frasa nomina, pelengkap frasa verba, pelengkap frasa ajektiva, dan pelengkap frasa numeralia atau preposisi (Samsuri, 1982, p.302-323). Terdapatnya transformasi sematan menjadikan variasi dalam pembentukan kalimat, sehingga kalimat tidak terlihat monoton. Variasi yang bisa dilihat dari adanya proses transformasi sematan adalah adanya bentukan kalimat dasar ke kalimat turunan, variasi struktur kalimat, dan variasi panjang pendeknya kalimat. 
Berdasarkan transformasi sematan yang terdapat pada teks terjemahan Alquran, ada tiga bahasan dalam penelitian ini. Petama, mengidentifikasi jenis transformasi sematan yang terdapat pada teks terjemahan Al-quran. Keda, memaparkan proses terjadinya transformasi sematan pada teks terjemahan Alquran. Ketiga, menjelaskan kaidah transformasi yang terdapat pada teks terjemahan Alquran yang mengandung etika berbahasa.

\section{METODE}

Penelitian ini merupakan penelitian kualitatif. Teknik pengumpulan data dalam penelitian ini dilakukan secara triangulasi, analisis data bersifat induktif/ kualitatif, dan hasil penelitian kualitatif lebih menekankan makna. Data dalam penelitian ini berupa kalimat transformasi sematan yang terdapat pada teks terjemahan Alquran yang mengandung etika berbahasa, sedangkan sumber datanya adalah teks terjemahan Alquran yang mengandung etika berbahasa. teknik pengumpulan data dilakukan dengan teknik dokumentasi, simak, dan catat. Data dalam penelitian ini diuji keabsahannya dengan teknik triangulasi. Penelitian ini menggunakan teknik triangulasi sumber data. Teknik analisis data dilakukan dengan metode padan intralingual dan padan ekstralingual. Metode padan intralingual adalah metode analisis dengan cara menghubungkan-bandingkan unsur-unsur yang bersifat lingual, baik yang terdapat dalam satu bahasa maupun dalam beberapa bahasa yang berbeda (Mahsun, 2006, p.112). Metode padan intralingual yang digunakan adalah teknik hubung banding membedakan (HBB).

\section{HASIL DAN PEMBAHASAN}

1. Jenis Transformasi Sematan Klausa Relatif pada Teks Terjemahan Alquran yang Mengandung Etika Berbahasa.

a. Data (1) Terjemahan Surat AlBagarah (2): 40

"Hai Bani Israil, ingatlah akan nikmat$\mathrm{Ku}$ yang tdah Aku anugerahkan kepadamu, dan penubilah janjimu kepadaKu, niscaya Aku penuhi janji-Ku kepadamu, dan hanya kepadaKurlah kamihanustakut”.

1) Data (1) berasal dari proses transformasi berikut.

(1a) Hai Bani Israil, ingatlah akan nikmat-Ku.

(1b) Nikmat-Ku itu telah Aku anugerahkan kepadamu.

(1c) Penuhilah janjimu kepada$\mathrm{Ku}$, niscaya $\mathrm{Aku}$ penuhi janji-Ku kepadamu, dan hanya kepada-Ku-lah kamu harus takut. Frase "nikmat-Ku" pada (1b) dilesapkan dan diganti dengan partikel yang Itulah sebabnya transformasi ini termasuk transformasi sematan klausa relatif.

2) Kaidah transformasi.

Pada data (1) terjadi proses transformasi rapatan pada (1a) dahulu, baru dilakukan proses transformasi sematan pada (1a dan 1b), kemudian dilakukan penggabungan dengan transformasi pada (1c).

b. Data (2) Terjemahan Surat AlBaqarah (2): 204

"Dan di antara manusia ada arangyang ucapannya tentang kehidupan dunia menanik hatimu dan dipesaksikannya kepada Allah (atas kebenaran) is hatinya, padahal ia penantangyangypaling keas".

(2i) "Dan d antara namsia ada arang yang ucapannya tentang kehidupan dunia 
menarik hatimu dan dipesaksikarmya kepada Allah (atas kebenaran) is hatinga".

1) Data (2i) berasal dari proses transformasi berikut.

(2ia) Dan di antara manusia ada orang.

(2ib) Orang itu ucapannya tentang kehidupan dunia menarik hatimu.

(2ic) Ucapannya tentang kehidupan dipersaksikannya kepada Allah.

Kata "orang" pada (2ib) dilesapkan dan diganti dengan partikel yang Itulah sebabnya transformasi ini termasuk transformasi sematan klausa relatif.

(2ii) "Padahal ia penartang yang paling keras".

2) Data (2ii) berasal dari proses transformasi berikut.

(2iia) Ia penantang.

(2iib) Penantang itu paling keras.

Penantang pada kalimat (3iib) dilesapkan dan diganti dengan partikel yang Itulah sebabnya transformasi ini disebut transformasi sematan klausa relatif.

3) Kaidah transformasi.

Data (2i) terjadi proses transformasi sematan pada (2ia dan 2ib) dahulu, baru dilakukan penggabungan dengan transformasi pada (2ic). Transformasi (2iia) dan (2iib) dilakukan terlebih dahulu, setelah itu baru dipertentangkan dengan gabungan $(2 \mathrm{i} a+2 \mathrm{ib})$ dan (2ic).

c. Data (3) Terjemahan Surat AnNissa' (2): 13

"Mereka itu adalah orang-orang yang Allah mengetahui apa yang di dalam hati mereka. Karena itu bepalingah dari modka dan berilah metka pdajaran, dan katakanlah kepada mekka pekkataan yang bedbkas dalam din metka”.

1) Data (3) berasal dari proses transformasi berikut.

(3a) Karena itu, beepalingah dan merka dan beilah merka pdajaran, dan katakanlah kepaca mekka perkataan

(3b) Pekkataan itu berbkas dalam din medka.

Kata "perkataan" pada (3b) dilesapkan dan diganti dengan partikel yang Inilah yang disebut dengan transformasi sematan klausa relatif.

2) Kaidah transformasi.

Data (3) terjadi proses transformasi rapatan pada (3a) dahulu, setelah itu baru dilakukan transformasi sematan pada (3a dan 3b).

d. Data (4) Terjemahan Surat AlMaidah(5): 13

"(Tetapi) karena mereka melanggar janjinya, kami kutuk mereka dan kami jadikan hati mereka keras membatu. Medka suka mengubah pekkataan (Allah) dan tempat-tempatrya, dan nerka (sengja) mdupakan słagjan dari apa yang medka diperingatkan dengamya, dan kamu (Muhammad) senantiasa akan milhat kkkhianatan dai mokka, keuali sedkit d antara modka, maka maakkanlah meka dan biarkanlah metka, Sesungguhrya Allah meryukai arangorang yang berbuat ihsan".

1) Data (4) berasal dari proses transformasi berikut.

(4a) Merka suka mengubah pekkataan (Allah) dai tempattempatrya, dan mitka (sengaja) milupakan sdbagian dai apa yang mereka diperingatkan dengannya, dan kamu (Muhammad) senantiasa akan melihat kekhianatan dari metka, keavli sedkit di antara mekka, maka maafkanlah medka dan 
biakkanlah merka, sesunguhrma Allahmeryukai orangforang (4b) Orangforangitu betbuat ihsan Kata ulang "orang-orang" pada (4b) dilesapkan dan diganti dengan partikel yang Inilah yang disebut dengan transformasi sematan klausa relatif.

2) Kaidah transformasi.

Data (4) terjadi proses transformasi rapatan pada (4a) dahulu, setelah itu baru dilakukan transformasi sematan pada (4a dan 4b).

e. Data Data (5) Terjemahan Surat AlMaickh(5): 85

"Maka Allah memberi mereka pahala terhadap perkataan yang mereka ucapkan (yaitu) surge yang mengalir sungai-sungai di dalamnya, sedang mereka kekal di dalamnya. Dan itullah balasan (bagi) arangforang yang beduat kebaikan (yang ikhlas keimanamya)".

1) Data (5) berasal dari proses transformasi berikut.

(5a) Dan itulahbalasan (bagi) arang arang

(5b) Orangforang itu beduat kebaikan (yangikhlaskeimananna). Kata ulang "orang-orang" pada (5b) dilesapkan dan diganti dengan partikel yang Inilah yang disebut dengan transformasi sematan klausa relatif.

2) Kaidah transformasi.

Data (5) terjadi proses transformasi sematan pada (5a dan $5 b)$.

f. Data (6) Terjemahan Surat AlMaickh(5): 101

"Hai arangforang yang baiman, janganlah kamu menanyakan hal-hal yangjika diterangkan kepadam, niscaya memusahkan kamu dan jika kamu mmanyakan di waktu Al-Quran itu seckng dununkan, niscaya akan diterangkan kepadamu Allah memaafkan tentang hal-hal itu. Allah
Maha Pengampun lagi Maha Penyantun."

1) Data (6) berasal dari proses transformasi berikut.

(6a) Hai arangforangyangbaiman

(6b) Janganlah kamı menanyakan hal-hal.

(6c) Hal-hal itu jika diterangkan kepadamu

(6d) Niscaya meryusahkan kamu dan jika kamı menanyakan di waktuAl- Quran itu seckng ditununkan, niscaya akan dterangkan kepadamı

Kata ulang "hal-hal" pada (6c) dilesapkan dan diganti dengan partikel yang Inilah yang disebut dengan transformasi sematan klausa relatif.

2) Kaidah transformasi.

Data (6) terjadi proses transformasi rapatan pada (6a dan $6 b$ ) dahulu, setelah itu baru dilakukan transformasi sematan pada (6a+6b dan 6c), kemudian digabungkan dengan transformasi pada (6d).

g. Data (7) Terjemahan Surat AlAn'aam(6): 108

"Dan janganlah kamu memaki sembahan-sembahan yang merka serbah sdain Allah maka medka akan mmaki Allah dengan milampaui batas tanpa pengtahuan Demikianlah Kami perintah bagi setiap umat-umat mereka. Kemudian kepada Tuhan merekalah kembali mereka, lalu dia memberikan kepada mereka apa yang mereka kerjakan."

1) Data (7) berasal dari proses transformasi berikut.

(7a) Dan janganlah kamu memaki sembahan-senbahan

(7b) Serbahan-sembahan itu nerka sembah sdainAllah

(7c) Medka akan memaki Allah dengan malampaii batas tanpa pengtahuan 
Kata ulang "sembahansembahan" pada (7b) dilesapkan dan diganti dengan partikel yang Inilah yang disebut dengan transformasi sematan klausa relatif.

2) Kaidah transformasi.

Data (7) terjadi proses transformasi sematan pada (7a dan $7 b$ ) dahulu, setelah itu baru terjadi proses transformasi rapatan (simpulan) pada $[(7 a+7 b)$ dan $(7 c)]$.

2. Proses Transformasi Sematan Klausa Relatif berdasarkan Tempat Unsur yang Disematkan.

a. Unsur sematan ada yang disematkan di awal

Data ini unsur sematan berada di awal, setelah itu baru diikuti dengan transformasi rapatan. Variasi yang muncul adalah unsur sematannya ada yang satu dan ada yang dua, begitu pula dengan unsur rapatannya ada yang satu dan ada yang dua, namun unsur sematan tetap berada di awal.

1) Data (8): S-R (Sematan-Rapatan) Terjemahan Surat Al-An'aam(6): 108

"Dan janganlah kamu memaki serbahan-senbahan yang merka sembah sdain Allah maka medka akan memaki Allah dengan mdampaui batas tampa pengtahuan".

Data (8) berasal dari proses transformasi berikut.

(8a) Dan janganlah kamu memaki sembahan-sembahan.

(8b) Sembahan-sembahan itu mereka sembah selain Allah.

(8c) Mereka akan memaki Allah dengan melampaui batas tanpa pengetahuan.

Kata ulang "sembahansembahan" pada (8b) dilesapkan dan diganti dengan partikel yang Inilah yang disebut dengan transformasi sematan klausa relatif.

2) Kaidah transformasi.

Data (8) terjadi proses transformasi sematan pada (8a dan 8b) dahulu, setelah itu baru terjadi proses transformasi rapatan (simpulan) pada $[(8 \mathrm{a}+8 \mathrm{~b})$ dan $(8 \mathrm{c})]$.

b. Unsur sematan ada yang disematkan di tengah

Data ini unsur sematan berada di tengah. Transformasi rapatan terjadi terlebih dahulu, setelah itu baru sematan, kemudian rapatan lagi. Jadi, unsur sematan diapit oleh dua rapatan.

1) Data (9): R-S-R (RapatanSematan-Rapatan)

Terjemahan Surat Al-Bacarah(2): 40

"Hai Bani Israil, ingatlah akan nikmat-Ku yang telah Aku anugrahkan kepadamu, dan penuhilah janjimu kepadaKu, niscaya Aku penuhi janji-Ku kepadamu, dan hanya kepadaKutlah kamihanus takut".

Data (9) berasal dari proses transformasi berikut.

(9a) Hai Bani Israil, ingatlah akan nikmat-Ku

(9b) Nikmat-Ku itu tdah Aku anuggahkan kepadamu

(9c) Penuhilah janjimu kepadaKu, niscaya $\mathrm{Aku}$ penuhi janji-Ku kepadamu, dan hanya kepada-Kutlah kamu hanus takut.

Frase "nikmat-Ku" pada (9b) dilesapkan dan diganti dengan partikel yang Itulah sebabnya transformasi ini termasuk transformasi sematan klausa relatif.

2) Kaidah transformasi.

Data (9) terjadi proses transformasi rapatan pada (9a) dahulu, baru dilakukan proses transformasi sematan pada (9a dan 9b), kemudian dilakukan 
penggabungan dengan

transformasi pada (9c).

c. Unsur sematan ada yang disematkan di akhir

Data ini unsur sematan berada di akhir dan transformasi rapatan terjadi di awal. Variasi yang muncul adalah unsur sematannya ada yang satu dan ada yang dua, namun unsur sematan tetap berada di awal.

1) Data (10): R-S (RapatanSematan)

Terjemahan Surat An-Nissa' (2): 13

"Karena itu, berpalinglah dari merka dan beilah metka pdajaran, dan katakanlah kepada medka perkataan yang berbokas dalam din mereka”.

Data (10) berasal dari proses transformasi berikut.

(10a) Karena itu, berpalinglah dari mereka dan berilah mereka pelajaran, dan

katakanlah kepada mereka perkataan.

(10b) Perkataan itu berbekas dalam diri mereka.

Kata "perkataan" pada (10b) dilesapkan dan diganti dengan partikel yang Inilah yang disebut dengan transformasi sematan klausa relatif.

1) Kaidah transformasi.

Pada data (10) terjadi proses transformasi rapatan pada (10a) dahulu, setelah itu baru dilakukan transformasi sematan pada (10a dan 10b).

d. Unsur sematan ada yang disematkan di awal dan akhir

Data ini unsur sematan berada di awal dan akhir, sedangkan transformasi rapatan berada di tengah. Jadi, rapatan diapit oleh dua sematan. Variasi yang muncul adalah unsur rapatannya ada yang satu dan ada yang dua, namun unsur sematan tetap berada di awal dan akhir.
1) Data (11): S-R-R-S (Sematan, Rapatan, Rapatan, Sematan)

Terjemahan Surat Al-Baqarah(2): 204

"Dan d antara manusia ada arang yang ucapannya tentang kehidupan dunia menarik hatimu dan dpesaksikannya kepada Allah (atas kebenaran) is hatinya, padahal ia penantangyangpalingkeras".

(11i) "Dan di antara namsia ada orang yang urapannya tentang kehidupan dunia menarik hatimu dan dpersaksikannya kepada Allah (atas keßonaran) is hatinya".

Data (11i) berasal dari proses transformasi berikut.

(11ia) D an di antara manusia ada orang.

(11ib) Orang itu ucapannya tentang kehidupan dunia menarik hatimu.

(11ic) Ucapannya tentang kehidupan dipersaksikannya kepada Allah.

Kata "orang" pada (11ib) dilesapkan dan diganti dengan partikel yang Itulah sebabnya transformasi ini termasuk transformasi sematan klausa relatif.

(11ii) "Padahal ia penantang yang palingkeras".

Data (11ii) berasal dari proses transformasi berikut.

(11iia) Ia penantang.

(11iib) Penantang itu paling keras.

Penantang pada kalimat (11iib) dilesapkan dan diganti dengan partikel yang Itulah sebabnya transformasi ini disebut transformasi sematan klausa relatif.

2) Kaidah transformasi.

Data (11i) terjadi proses transformasi sematan pada (11ia dan 11ib) dahulu, baru dilakukan penggabungan 
transformasi pada (11ic).

Transformasi (11iia) dan (11iib)

dilakukan terlebih dahulu, setelah itu baru dipertentangkan dengan gabungan (11ia+11ib) dan (11ic).

e. Unsur sematan ada yang disematkan

di tengan dan akhir

1) Data (12): R-S-R-S (RapatanSematan-Rapatan-Sematan)

Terjemahan Surat Al-Ahzab(33): 32

"Maka janganlah kamı tunduk keika berbicara shingga betkeinginanlah arang yang ada penyakit dalam hatinya, dan urapkanlah perkataanyangbaik.

(12i) "Maka janganlah kamu tunduk ketika bedicara shingga berkeinginanlah orang yang ada penyakit dalamhatinya”.

Data (12i) berasal dari proses transformasi berikut.

(12ia) Maka janganlah kamu tunduk ketika berbicara.

(12ib) Berkeinginanlah orang itu.

(12ic) Orang itu ada penyakit dalam hatinya.

Kata "orang" pada (30ic) dilesapkan dan diganti dengan partikel yang Inilah disebut proses transformasi sematan klausa relatif.

(12ii) "Ucapkanlah perkataan yang baik".

Data (12ii) berasal dari proses transformasi berikut.

(12iia) Ucapkanlah perkataan.

(12iib) Perkataan itu baik.

Kata "perkataan" pada (12iib) dilesapkan dan diganti dengan partikel yang Inilah yang disebut dengan proses transformasi sematan klausa relatif.

2) Kaidah transformasi.

Pada data (12i) terjadi proses transformasi rapatan (hasilan) pada (12ia dan 12ib) dahulu, setelah itu baru dilakukan transformasi sematan pada

(12ia+12ib) dan (12ic).

Transformasi sematan pada (12iia dan 12iib) dilakukan terlebih dahulu, setelah itu baru digabungkan dengan transformasi pada (12ia+12ib) dan (12ic).

f. Unsur sematan ada yang disematkan di awal dan tengah

Data ini unsur sematan berada di awal dan tengah, sedangkan transformasi rapatan berada di tengah dan akhir. Variasi tersebut membentuk pola berurutan, namun tetap diawali sematan dan diakhiri rapatan. Terdapat 3 data yang unsur penyematnya berada di awal dan tengah.

1) Data (13): S-R-S-R (SematanRapatan-Sematan-Rapatan)

Terjemahan Surat Al-Mujadalah (58): 9

"A pakah tiada kamu pehatikan arangarang yang tdah dilarang mengadakan penhicaraan rahasia, kemudian merka kenbali (mengrjakan) larangan itu dan metka mengadkan penhicaraan rahasia untuk berbuat dbsa, permsuhan dan durhaka kepada Rasul”.

(13i) Apakah tiada kamu perhatikan orangarang yang tdah dlarang mengadakan penbicaraan rahasia, kemudian merka kenbali (mengejakan) laranganitu.

Data (13i) berasal dari proses transformasi berikut.

(13ia) Apakah tiada kamu perhatikan orang-orang.

(13ib) Orang-orang itu telah dilarang mengadakan pembicaraan rahasia.

(13ic) Mereka kembali (mengerjakan) larangan itu.

Kata ulang "orang-orang" pada (13ib) dilesapkan dan diganti dengan partikel yang. Inilah 
sebabnya transformasi ini disebut transformasi sematan klausa relatif.

(13ii) Merka mengadkan penbicaraan rahasia untuk beturat dbsa, permsuhan dan durhaka kepada Rasul.

Data (13ii) berasal dari proses transformasi berikut.

(13iia) Mereka mengadakan pembicaraan rahasia.

(13iib) Mereka berbuat dosa.

(13iic) Mereka mengadakan permusuhan, mereka durhaka kepada Rasul.

Kata "mereka" pada (13iib) dilesapkan dan diganti dengan partikel untuk. Itulah sebabnya transformasi ini disebut transformasi sematan pelengkap frase ajektiva.

2) Kaidah transformasi

Data (13i) terjadi proses transformasi sematan pada (13ia dan 13ib) dahulu, setelah itu baru dilanjutkan dengan transformasi pada (13ic). Transformasi sematan pada (13iia dan 13iib) dilakukan terlebih dahulu, setelah itu baru digabungkan dengan transformasi pada (13iic), lalu digabungkan dengan transformasi pada (13ia+13ib dan 13ic).

g. Unsur sematan ada yang disematkan di awal, tengah, akhir

Data ini unsur sematan berada di awal, tengah, dan akhir, sedangkan transformasi rapatan berada di tengah. Variasi tersebut membentuk pola berurutan, namun tetap diawali dan diakhiri dengan sematan. Terdapat 3 data yang unsur penyematnya berada di awal, tengah, dan akhir.

1) Data (14): S-R-S-R-S (SematanRapatan-Sematan-RapatanSematan)
Terjemahan Surat Al-Balad (90): 17

"Dan dia temasuk arangarangyang beriman dan saling berpesan untuk bersabar dan saling berpesan untuk betkasihsayangy".

(14i) Dan da temasuk arangarang yangbeiman

Data (14i) berasal dari proses transformasi berikut.

(14ia) Dan dia termasuk orangorang.

(14ib) O rang-orang itu beriman.

Kata ulang "orang-orang" pada (14ib) dilesapkan dan diganti dengan partikel yang Inilah sebabnya transformasi ini disebut transformasi sematan klausa relatif.

(14ii) "saling bespesan untuk bersabar dan saling berpesan untuk berkasih sayang".

Data (49ii) berasal dari proses transformasi berikut.

(14iia) Orang-orang itu saling berpesan

(14iib) O rang-orang itu bersabar. Kata ulang "orang-orang" pada (14iib) dilesapkan dan diganti dengan partikel untuk. Inilah sebabnya transformasi ini disebut transformasi sematan pelengkap frase verba.

(14iii) salingberpesan untuk betkasih sayang

Data (14iii) berasal dari proses transformasi berikut.

(14iiia) Orang-orang itu saling berpesan.

(14iiib) O rang-orang itu berkasih sayang.

Kata ulang "orang-orang" pada (14iiib) dilesapkan dan diganti dengan partikel untuk. Inilah sebabnya transformasi ini disebut transformasi sematan pelengkap frase verba.

2) Kaidah transformasi 
Data (14i) terjadi proses transformasi sematan pada (14ia dan 14ib). Transformasi sematan pada (14iia dan 14iib) dilakukan terlebih dahulu, setelah itu baru digabungkan dengan transformasi pada (14iiia dan 14iiib), dan digabungkan lagi dengan transformasi pada (14ia dan 14ib).

\section{Kaidah Transformasi Sematan}

\section{Klausa Relatif}

a. Pada Kalimat Kompleks

Struktur kalimat kompleks, satu kalimat tidak hanya terdiri atas satu klausa, tetapi beberapa klausa. Pada kajian ini, kexomplekan didasarkan pada variasi jumlah sematan dan rapatan dalam susunan kalimat.

1) Sematan-Rapatan-Sematan-

Rapatan (disingkat S-R-S-R)

Data (15) Terjemahan Surat AlMujadalah(58): 9

\section{“A pakah tiada kamu perhatikan arangfarangyangtdah dilarang \\ Sematan}

mengadakan penhicaraan rahasia, kemudan merka kembali

Rapatan

(mengejakan) larangan itu dan merka mengadakan pembicaraan

Sematan

rahasia untuk berbuat dosa, permusuhan dan durhaka kepada Rasul". Rapatan

2) Sematan-Rapatan-Sematan (disingkat S-R-S)

Data (16) Terjemahan Surat AnNissa' (4): 5

"Dan janganlah kamu menyerahkan kepada arangarangyang

Sematan bolum sempuma akalnya, harta kamiyangdijadkan Allah untuk Sematan

kamu sdbagai pokok kdhidupan”. Rapatan

b. Pada Kalimat Sederhana

Tingkat kesederhanaan kalimat dilihat berdasarkan variasi transformasi yang terdapat dalam kalimat. Kalimat komplek di dalamnya terdapat transformasi sematan dan transformasi rapatan atau sematannya lebih dari satu, sedangkan kalimat sederhana di dalamnya hanya terdapat satu transformasi sematan.

1) Data (17) Terjemahan surat AlBaqarah (2): 235

"Dan janganlah kamu berázam (betteaphati) untuk beraqad nikah". Sematan

2) Data (18) Terjemahan Surat AlMujadalah(58): 9

"Cukuplah bag meika meraka Jahanam yang akan merka masuki."

Sematan

\section{SIMPULAN}

Berdasarkan pembahasan di atas, dapat diperoleh dua simpulan bahwa (1) tempat unsur sematan pada teks terjemahan Alquran yang mengandung etika berbahasa ada yang di awal, tengah, akhir, awal-akhir, tengah-akhir, akhir-tengah, dan awal-tengahakhir, dan; (2) kaidah transformasi berdasarkan jenis kalimat terbagi menjadi dua, yaitu kalimat kompleks dan kalimat sederhana. Kalimat kompleks terdiri lebih dari satu proses transformasi yang menghasilkan formasi: Sematan-RapatanSematan, Sematan-Rapatan-SematanRapatan. 


\section{DAFTAR RUJUKAN}

Chaer, A., \& Agustina, L. (2010). Sosidinguistik pekenalan aval. Jakarta: Rineka Cipta.

Mahsun. (2006). Metode penditian bahasa: tahapan strategi, moded dan tdkniknya Jakarta: PT. Raja Grafindo Persada.

Sabardila, A. (2003). Etika berbahasa dalam isam kajian secara linguistik. FK IP: Universitas Muhammadiyah Surakarta.
Markhamah, Ngalim, A., Muinudinillah, B., Sabardila, A., \& Susilowati. (2012). Transformasi penggantian pada teks terjemahan Alquran yang mengandung etika berbahasa. Kajian Lingistik dan Sastra, 24(2), 139-151

Samsuri. (1982). Tata kalimat bahasa Indonesia Malang: Sastra Hudaya.

Tim Penyusun. (2005). Kamus Besar Bahasa Indonesia (Edis ke3). Jakarta: Pusat Bahasa D epartemen Pendidikan Nasional Balai Pustaka. 